\title{
DIETARY POLYDEXTROSE INCREASES CALCIUM ABSORPTION IN NORMAL RATS
}

\author{
Polidextrose aumenta a absorção de cálcio em ratos
}

\author{
Elisvânia Freitas dos SANTOS $^{1}$, Kathia Hitomi TSUBOI ${ }^{1}$, Marina Rachel ARAÚJO ${ }^{2}$, \\ Arthur C. OUWEHAND ${ }^{2}$, Nelson Adami ANDREOLLO ${ }^{2}$, Celio Kenji MIYASAKA ${ }^{1}$
}

ABCDDV/673

Santos EF, Tsuboi KH, Araújo MR, Ouwehand AC, Andreollo NA, Miyasaka CK. Dietary polydextrose increase calcium absorption in normal rats. ABCD Arq Bras Cir Dig 2009;22(4):201-5

ABSTRACT - Background - Gastric surgery is known to cause bone disorders, possibly related to an impaired capacity for the absorption of dietary calcium. Aim - To verify if polydextrose (PDX) could stimulate calcium absorption in partially gastrectomized and sham operated rats. Methods - The rats were laparotomized (sham-operated control) or partially gastrectomized (Billroth II), in groups of 20 each. Half in each operated group were fed a control diet (AIN-93M) without PDX or the same diet containing (PDX 50g/Kg of diet) for eight weeks. The rats were divided into four subgroups: sham-operated and gastrectomized without PDX; sham-operated and gastrectomized with PDX. On the final day of the study, total blood was collected for determination of serum calcium concentration. Results - In the diet with PDX, excretion of calcium in the feces was significantly lower than in the groups not receiving PDX, irrespective of the operation. Apparent calcium absorption and serum calcium was higher in the sham operated PDX fed group than in the control group. In sham operated rats, the calcium concentration in bone was higher in the PDX fed group. Conclusion - The polydextrose feeding increased calcium absorption and bone calcium concentration in normal rats, which may be relevant for decreasing the risk of osteoporosis. Partially gastrectomy did not affect the bone calcium concentration in 56 days of experimental period.

HEADINGS - Prebiotics. Polydextrose. Gastrectomy. Calcium. Rat.

\section{INTRODUCTION}

Extensive gastric surgery is known to cause bone disorders (osteomalacia/osteoporosis) ${ }^{7,9}$ possibly related to an impaired capacity for the absorption of dietary calcium ${ }^{1,5}$. The absence of gastric acid after gastric resection may impair bioavailability of insoluble dietary calcium because gastric acid is the most important factor for solubilization of otherwise insoluble calcium salts ${ }^{5}$.

The stomach plays an important role in calcium homeostasis, but the mechanism of gastric action is not yet completely understood. Recently, there have been several reports indicating that indigestible carbohydrates, such fructooligosaccharides ${ }^{10,11}$, inulin ${ }^{14}$, partially hydrolysed guar gum ${ }^{4}$ and polydextrose ${ }^{5}$, stimulate mineral absorption.

Fiber is an essential nutrient in a healthy diet, contributing to health maintenance and preventing the occurrence of different disease. Polydextrose is a soluble fiber that is not digested in the upper gastrointestinal tract $^{3}$. Beneficial bifidogenic and fiber-like effects of polydextrose have been previously demonstrated in humans ${ }^{6}$. The effects of polydextrose on mineral absorption have been little evaluated.

Trabalho realizado na Faculdade de Engenharia de Alimentos ${ }^{1}$ e Laboratório de Enzimologia e Carcinogênese Experimental do Núcleo de Medicina e Cirurgia Experimental ${ }^{2}$ da Faculdade de Ciências Médicas da UNICAMP, Campinas, SP, Brasil

Endereço para correspondência: Elisvânia Freitas dos Santos, e-mail: elisvania@gmail.com
The ingestion of the polydextrose on calcium absorption was only evaluated in the total-gastrectomized rats ${ }^{5}$.

Therefore, the aim of current study was to examine effects of feeding polydextrose on calcium absorption and bone mineralization of normal and partially gastrectomized rats.

\section{METHODS}

\section{Animals and surgical procedure}

Forty male Wistar rats (Cemib/Unicamp, Campinas, Brazil) $250.0 \pm 5 \mathrm{~g}$ of body weight were kept in collective cages in a room with controlled temperature $\left(22 \pm 1^{\circ} \mathrm{C}\right)$, humidity (60-70\%), cycle of 12 hours day-night (lights on at 7:00 am), with diet and deionized water ad libitum were used. The animals were randomly assigned to two groups of 20 animals each. One group of 20 was submitted to anterior truncal vagotomy and to partial gastrectomy (Billroth II). The sham operated group (20 animals) was submitted to the same surgical stress, where the abdominal cavity was maintained open for approximately 45 minutes, which it is the duration of a Billroth II operation. The rats were anesthetized with sodium thiopental $(25 \mathrm{mg} / \mathrm{Kg}$ body weight, intravenous). The experimental protocol was previously approved by the Committee of Ethics in Animal Experimentation (CEEA) of the State University of Campinas - UNICAMP (record nº 839-1, 08/06/2005). 


\section{Experimental groups and diets}

After 15 days of the procedure, the rats were divided randomly into four experimental subgroups (sham-operated vs. gastrectomy and control vs. polydextrose diet), (Sham/ Control: $\mathrm{n}=10$; Sham/PDX: $\mathrm{n}=10$; Gastrectomy/Control: $\mathrm{n}$ $=8 ;$ Gastrectomy/PDX: $\mathrm{n}=9$ ). Three rats of gastrectomized group died during the experiment. They were fed the assigned experimental diets for eight weeks. The control and experimental feeds were prepared according to the AIN-93M formulation ${ }^{13}$. Polydextrose (Litesse Ultra, Danisco Brazil Ltda, Cotia, Sao Paulo, Brazil) was added at $50 \mathrm{~g} / \mathrm{Kg}$ diet by replacing sucrose in the control diet. The composition of the two experimental diets (control and polydextrose) is shown in Table 1. One-half of the gastrectomized and sham-operated rats were fed the control diet, and the remaining were fed the polydextrose containing diet.

TABLE 1 - Composition of experimental diets

\begin{tabular}{lll}
\hline Ingredients, $\mathbf{g} / \mathbf{K g}$ & Control diet & PDX $^{\mathbf{1}}$ diet \\
\hline Cornstarch $^{2}$ & 466 & 466 \\
Dextrinized cornstarch $^{2}$ & 155 & 155 \\
Casein $^{3}$ & 140 & 140 \\
Soybean oil $^{4}$ & 40 & 40 \\
Cellulose $^{5}$ & 50 & 50 \\
Sucrose $^{6}$ & 100 & 50 \\
Polydextrose $^{1}$ & 0 & 50 \\
Mineral mixture $^{7}$ & 35 & 35 \\
Vitamin mixture $^{7}$ & 10 & 10 \\
L-Cystine $^{8}$ & 1.8 & 1.8 \\
Choline bitartrate $^{9}$ & 2.5 & 2.5 \\
Tert-butylhydroquinone $^{10}$ & 0.008 & 0.008 \\
\hline
\end{tabular}

1 Polydextrose (PDX, 50 g/Kg diet) Litesse Ultra, Danisco Brasil Ltda, Cotia, Sao Paulo, Brazil. Refined polydextrose powder.

2 Cornstarch and dextrinized cornstarch (Corn Products Brasil - Ingredients Industrys Ltda, Mogi Guaçu, Sao Paulo, Brazil).

3 Plury Chemistry Ltda, Diadema, Sao Paulo, fabricate by Naarden Agro Products-Holland.

4 Mark Liza, Cargill do Brazil, Uberlandia, Minas Gerais, Brazil.

5 Mark Microcel, Blanver Pharmachemistry Ltda, Cotia, Sao Paulo, Brazil.

6 Refinery Uniao, Assis, Sao Paulo, Brazil.

7 Prepared according to the AIN-93M formulation (8). Formulate by M. Cassab Trade and Industry Ltda, Sao Paulo, Sao Paulo, Brazil.

8 Mark Synth C1027.01.AE; Diadema, Sao Paulo, Brazil.

9, 10 SIGMA Chemical Co., St. Louis, Mo, USA.

The animals were allowed free access to deionized water throughout the experimental period. For the prevention of the megaloblastic anemia, the gastrectomized rats received supplements of vitamin B12 (Cianocobalamin / 0.5mg/Kg / intramuscular) (Cianotrat 5000 - Institute Therapeutic Delta Ltda, Indaiatuba, São Paulo, Brazil) every two weeks, beginning one week after surgery ${ }^{18}$. The sham group received chloride of the sodium 0,9\% (Sanobiol Ltda, Pouso Alegre, Minas Gerais, Brazil). For feces collection, the animals were placed into individual metabolic cages, for three days in three periods on the 15th, 35th and 55th day of the experiment ${ }^{2}$.

The weight gain and the consumption of the diet of the animals were monitored three times a week, for eight weeks.

\section{Analytical methods}

On the final day of the experiment, all rats were anesthetized with sodic thiopental $(25 \mathrm{mg} / \mathrm{Kg}$ body weight). Whole blood was collected by cardiac puncture, and the animals were killed.
The serum calcium contents were determined by a commercially available colorimetric method (Laborlab, Guarulhos, São Paulo, Brazil).

Freeze-dried feces were weighed and milled. Diets and the powdered feces were dry-ashed at linearly increased temperatures up to $550 \mathrm{o} C$ for $6 \mathrm{~h}$ and then at $550 \mathrm{o} \mathrm{C}$ for 18 $h$ by a muffle furnace (Fornitec Industry and Trade Ltda, São Paulo, Brazil). Samples were heated with $0.5 \mathrm{~mL}$ concentrate HNO3 $65 \%$ and 0.15 mL (30 \%) H2O2 (Merck Brazil, São Paulo, Brazil) in closed pressurized Hostaflon tubes heated in microwave (DGT 100 Plus-Provecto, Jundiaí, São Paulo, Brazil). The determinations of fecal and dietary calcium were performed in an Optic Emission IRIS-AP (Thermo Jarrell Ash, Franklin - Massachusetts - USA) at the specialized Laboratory of Biominerals Chemical Analyses, Campinas, São Paulo-Brazil. The calculations were: apparent calcium absorption $(\mathrm{mg} /$ day $)=$ calcium intake $(\mathrm{mg} /$ day $)$ - fecal calcium excretion (mg/day) $)^{2}$.

The femur was removed after the death of the animals, the muscle was removed and the femur was frozen. The bone was burned in muffle furnace (Fornitec Indústria e Comércio Ltda, São Paulo,SP,Brazil) at $600^{\circ} \mathrm{C}$ to the obtain clear ashes. The determinations of bone calcium were performed in an Optic Emission Spectrometer IRIS-AP (Thermo Jarrell Ash, Franklin - Massachusetts - USA) at the specialized Laboratory of Biominerals Chemical Analyses Ltda, Campinas, São Paulo-Brazil.

\section{Statistical analysis}

The results were submitted to analysis of variance (ANOVA), with the use of Duncan's test for the comparison of the averages. The data were analyzed by two-way (treatment and diet) or three-way (treatment, diet and time). Differences were considered significant at $\mathrm{P}<0.05$. Data are expressed as means and standard error of mean (SEM) Statistica Ver 6.0® (Statsoft, Inc. Tulsa, USA) for Windows ${ }^{19}$.

\section{RESULTS}

\section{Body weight and food intake}

Initial body weight in sham-operated feeding groups was significantly higher than those in the corresponding gastrectomized rats $(\mathrm{P}<0.05)$. Final body weights in both gastrectomized rat groups were significantly lower than those in sham-operated rats $(\mathrm{P}<0.05)$. Total body weight gain was similar for all groups, except for gastrectomised rats fed the polydextrose diet $(\mathrm{P}<0.05)$. Food intake in gastrectomized rats eating the control diet was significantly lower compared to the other three groups $(\mathrm{P}<0.05)$ (Table 2).

\section{Weight wet and weight dry of feces}

In sham-operated and gastrectomized rats the mean wet and dry weight of the feces was significantly higher in rats that received the polydextrose diet then in rats that received the control diet $(\mathrm{P}<0.05)$ (Table 3$)$. 
TABLE 2 - Initial and final body weights, total body weight gain and food intake of sham-operated and gastrectomized rats fed diets with or without (control) polydextrose (PDX)

\begin{tabular}{|c|c|c|c|}
\hline $\begin{array}{l}\text { Treatments/ } \\
\text { Diets }\end{array}$ & $\begin{array}{l}\text { Initial body } \\
\text { weight (g) }\end{array}$ & $\begin{array}{l}\text { Fin a l body } \\
\text { weight (g) }\end{array}$ & $\begin{array}{l}\text { Total body Food intake } \\
\text { weight gain, (g/day) } \\
\text { (g/8 wk) }\end{array}$ \\
\hline
\end{tabular}

Sham

Control $(\mathrm{n}=264.50 \pm 3.43 \mathrm{ab} \quad 421.60 \pm 7.66 \mathrm{a} \quad 157.10 \pm 8.99 \mathrm{a} \quad 25.84 \pm 2.48 \mathrm{a}$ 10)

\begin{tabular}{lllll}
$\operatorname{PDX}(\mathrm{n}=10)$ & $275.20 \pm 5.00 \mathrm{a}$ & $421.70 \pm 10.61 \mathrm{a}$ & $146.50 \pm 8.60 \mathrm{a}$ & $26.29 \pm 2.39 \mathrm{a}$ \\
\hline
\end{tabular}

Gastrectomy

$\begin{array}{lllll}\text { Control }(\mathrm{n}=8) & 221.88 \pm 4.74 \mathrm{c} & 375.00 \pm 9.94 \mathrm{~b} & 153.13 \pm 6.62 \mathrm{a} & 21.02 \pm 1.10 \mathrm{~b}\end{array}$ \begin{tabular}{lllll} 
PDX $(\mathrm{n}=9)$ & $256.78 \pm 7.67 \mathrm{~b}$ & $391.44 \pm 8.24 \mathrm{~b}$ & $134.67 \pm 5.31 \mathrm{~b}$ & $24.87 \pm 2.70 \mathrm{a}$ \\
\hline
\end{tabular}

Each value represents a mean \pm SEM. Values in a column not sharing a superscript letters were significantly different, $\mathrm{P}<0,05$ (Duncan`s multiple range test).

TABLE 3 - Weigh wet and dry of the feces (g) collected at three time points $(15,35$ and 55 days) of the experimental phase. For three days each period of the groups sham-operated and gastrectomized rats fed diets with or without (control) polydextrose (PDX)

\begin{tabular}{lcc}
\hline \multirow{2}{*}{ Groups/Treatments } & \multicolumn{2}{c}{ Weigh feces $(\mathbf{g})$} \\
\cline { 2 - 3 } & Weigh Wet $(\mathbf{g})$ & Weigh Dry $(\mathbf{g})$ \\
\hline Sham & & \\
Control $(\mathrm{n}=10)$ & $4.62 \pm 0.22 \mathrm{~b}$ & $4.12 \pm 0.17 \mathrm{~b}$ \\
PDX $(\mathrm{n}=10)$ & $\mathbf{6 . 0 8} \pm \mathbf{0 . 4 2 a}$ & $\mathbf{5 . 0 1} \pm \mathbf{0 . 2 6 a}$ \\
\hline Gastrectomy & & \\
Control $(\mathrm{n}=8)$ & $5.42 \pm 0.46 \mathrm{~b}$ & $4.73 \pm 0.35 \mathrm{~b}$ \\
PDX $(\mathrm{n}=9)$ & $8.05 \pm 0.62 \mathrm{a}$ & $6.46 \pm 0.32 \mathrm{a}$ \\
\hline
\end{tabular}

Each value represents a mean \pm SEM. Values in a column not sharing a superscript letters were significantly different, $\mathrm{P}<0,05$ (Duncan`s multiple range test).

\section{Serum calcium concentration}

Partial gastrectomy lead to lower serum calcium concentrations compared to sham operated rats. However, this reduction could be counteracted by inclusion of polydextrose in the diet of the partially gastrectomized rats $(\mathrm{P}<0.05)$ (Figure 1).

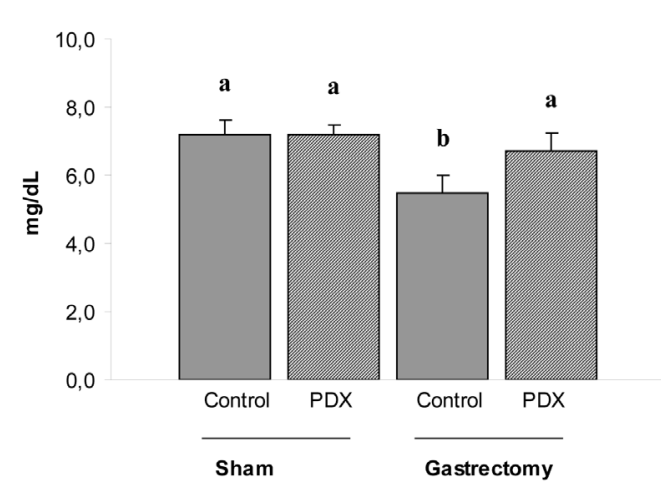

FIGURE 1 - Serum calcium in sham operated or gastrectomized rats fed diets with or without (control) polydextrose (PDX). Each value represents the means \pm SEM (Sham/Control: $\mathrm{n}=10$; Sham/PDX: $\mathrm{n}=10$; Gastrectomy/Control: $n=8$; Gastrectomy/PDX: $n=9$ ). Two ANOVA main effects (treatment and diet) and interactions (treatment $\mathrm{x}$ diet) were significant. Diet (control or PDX), treatment (with or without gastrectomy). Bars not sharing a common superscript are significantly different, $\mathrm{P}<$ 0.05 (Duncan`s multiple range test).

\section{Fecal calcium and apparent calcium absorption}

The concentration of calcium in feces in the shamoperated and partially gastrectomized receiving polydextrose enriched-diet was lower $(\mathrm{P}<0.05)$ as compared to the control diet (Figure 2). The apparent absorption of calcium by the sham-operated rats receiving polydextrose enriched-diet was higher as compared to the animals with control diet (Figure 3). However, this reached only significance for the sham operated rats $(\mathrm{P}<0.05)$.

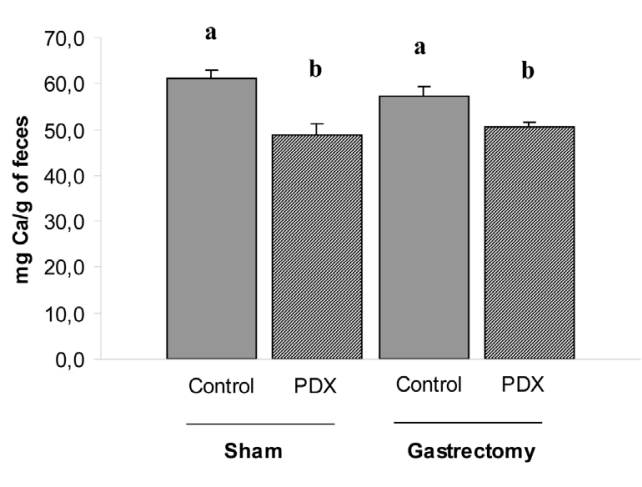

FIGURE 2 -Fecal calcium concentration (mg/g feces) in Sham operated or gastrectomized rats fed diets with or without (control) polydextrose (PDX). Each value represents the means \pm SEM (Sham/Control: $n=$ 10; Sham/PDX: $n=10$; Gastrectomy/Control: $n$ $=8$; Gastrectomy/PDX: $\mathrm{n}=9$ ). Diet (control or PDX), treatment (with or without gastrectomy). Bars not sharing a common superscript are significantly different, $\mathrm{P}<0.05$ (Duncan`s multiple range test)

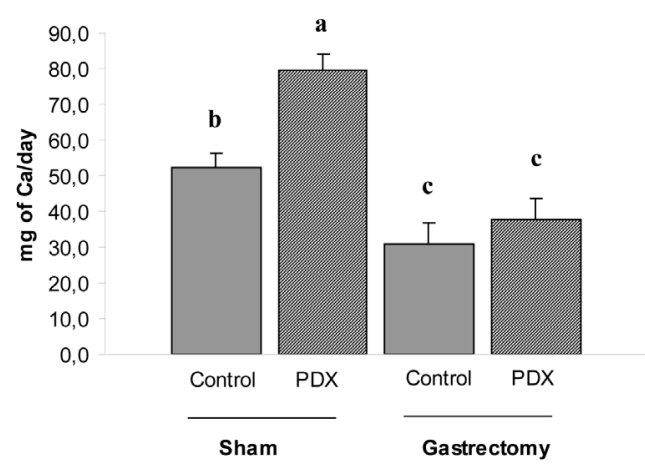

FIGURE 3 - Apparent calcium absorption in sham operated or gastrectomized rats fed diets with or without (control) polydextrose (PDX). Each value represents the means \pm SEM (Sham/Control: $n=$ 10; Sham/PDX: n=10; Gastrectomy/Control: $n$ = 8; Gastrectomy/PDX: n=9). Diet (control or PDX), treatment (with or without gastrectomy). Bars not sharing a common superscript are significantly different, $\mathrm{P}<0.05$ (Duncan`s multiple range test). 


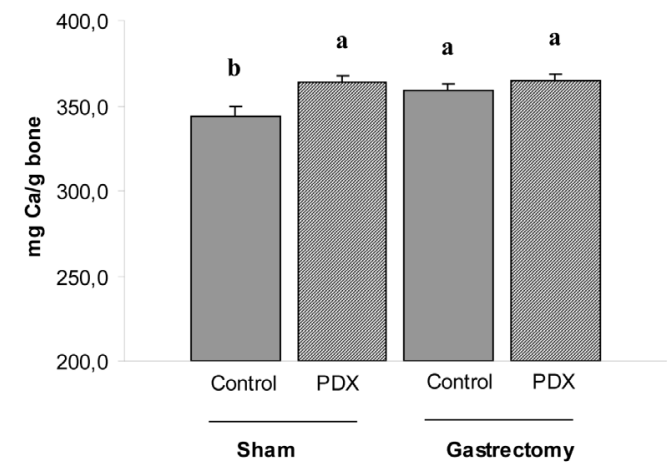

FIGURE 4 - Calcium concentration in the bone in sham operated and gastrectomized rats fed diets with or without (control) polydextrose (PDX). Each value represents the means \pm SEM (Sham/Control: $n=$ 10; Sham/PDX: n=10; Gastrectomy/Control: $n$ = 8; Gastrectomy/PDX: $\mathrm{n}=9$ ). Diet (control or PDX), treatment (with or without gastrectomy). Bars not sharing a common superscript are significantly different, $\mathrm{P}<0.05$ (Duncan`s multiple range test).

\section{DISCUSSION}

Body-weight gains in gastrectomized rats were lower than those in normal rats, except in animals fed the polydextrose diet. In spite of the fact that food intakes were lower in gastrectomized rats, however in rats fed the polydextrose diet this did not reach statistical significance (Table 2). The present study confirms observations on partial gastrectomy in adult rats where less feed consumption and smaller weight in gastrectomized animals was reported ${ }^{11}$. That smaller weight gain of the gastrectomized rats is likely to be associated with the smaller feed consumption due to a smaller size of the stomach, an important reason for this kind of treatment in humans. An earlier study with gastrectomized rats found that after the procedure metabolic changes occur that reduce the absorption of nutrients, causing a delay in growth of the animals ${ }^{5}$. The reduced weight gain in gastrectomized rats was also verified by Ohta et al. ${ }^{11}$. The results suggest that some metabolic changes rather than impaired nutrient absorption, is involved in the growth retardation in the gastrectomized rats.

Faecal outputs were significantly increased in shamoperated rats and gastrectomized fed with polydextrose (Table 3). These results are in agreement with a previous study on polydextrose ${ }^{5}$ and can be explained by the fiber properties of polydextrose.

The present research studied the serum calcium concentration in gastrectomized rats, and inclusion of polydextrose in the feed strikingly increased the serum calcium concentration. The reduced serum calcium in the operated rats suggests that the gastrectomy reduces the absorption of the calcium. Similar results have earlier been obtained by Axelson et al. ${ }^{1}$. These authors confirm that this is a similar process in humans where gastrectomy induces a progressive deficiency in the absorption in the calcium. They also suggest that the mucosa of the stomach may have a calcium tropic agent, gastrocalcin, which stimulates calcium absorption by the bone. Sakai et al. ${ }^{15}$, also verified reduced serum calcium in gastrectomized rats. Zittel et al. ${ }^{20}$ verified reduced calcium in humans with partial and total gastrectomy, suggesting that this is due to a reduced release of calcium from the diet, the increased intestinal flow and the removal of duodenum and jejunum. The sum of this these factors lead to a reduced serum calcium concentration.

We showed that partially gastrectomy strikingly reduced apparent calcium absorption. The results suggest that the employed experimental protocol really causes a depression in the absorption of dietary calcium. Some other studies showed that total gastrectomy in rats also reduces the calcium absorption ${ }^{5,11}$. Feeding polydextrose decreases excretion of calcium in feces and restored the of calcium absorption in normal (sham-operated) and partially in gastrectomized rats. These results agree with a previous study on polydextrose ${ }^{5}$. The present study suggests that both the large and small intestine are possibly responsible for the increases in calcium absorption with feeding polydextrose ${ }^{5}$.

The concentration of calcium in the bone in shamoperated rats eating the control diet was significantly lower compared to the other three groups $(\mathrm{P}<0.05)$. The bone is the main storage site of calcium of the organism and the eight weeks (56 days) after partially gastrectomy may be not enough to cause a sensitive reduction in bone calcium. In the previous study with total gastrectomy reduced bone mineralization $^{5}$. After the gastric resection the content of calcium in the bone is reduced and became more pronounced during the time ${ }^{12}$. These results were observed in other studies $5,1,12,16,17$.

Patients submitted to bariatric surgery present micronutrient deficiencies of vitamin B12, iron, calcium, and vitamin $\mathrm{D}$, and nutrient and mineral supplementation are essential for the treatment and prevention of nutritional and metabolic complications ${ }^{8}$. Therefore, the polydextrose could improve calcium absorption in these patients, and new studies in the future are suggested.

\section{CONCLUSIONS}

Polydextrose feeding increases calcium absorption and bone calcium concentration in normal rats, which may be relevant for decreasing the risk of osteoporosis. Partially gastrectomy did not affect the bone calcium concentration in 56 days of experimental period.

\section{ACKNOWLEDGEMENTS}

To National Council of Technological and Scientific Development (CNPq), Laboratory Biominerals Chemical Analyses Ltda and Johnson \& Johnson ${ }^{\circledR}$ for the surgical sutures. 
Santos EF, Tsuboi KH, Araújo MR, Ouwehand AC, Andreollo NA, Miyasaka CK. Miyasaka. A polidextrose aumenta a absorção de cálcio em ratos. ABCD Arq Bras Cir Dig 2009;22(4):201-5

RESUMO - Racional - A cirurgia gástrica é conhecida por causar desordens ósseas, possivelmente relacionado com a absorção do cálcio na dieta. Objetivo - verificar se polidextrose (PDX) poderia estimular a absorção de cálcio em ratos parcialmente gastrectomizados e ratos sham operados. Métodos - Os ratos foram laparotomizadas (sham-operados de controle) ou parcialmente gastrectomizados (Billroth II), em grupos de 20 animais cada. Metade de cada grupo operado foi alimentada com uma dieta controle (AIN-93M) sem PDX ou a mesma dieta contendo (PDX 50g/kg de ração) durante oito semanas. Os animais foram divididos em quatro subgrupos: sham-operados e gastrectomizados sem PDX; sham-operados e gastrectomizados com PDX. No dia final do estudo, sangue foi coletado para determinação da concentração de cálcio sérico. Resultados - Na dieta com PDX, a excreção de cálcio nas fezes foi significativamente menor do que nos grupos que não recebem PDX, independentemente da operação. Absorção aparente de cálcio e cálcio sérico foi maior no sham operados com PDX do que no grupo controle. Em ratos sham operados, a concentração de cálcio nos ossos foi maior no grupo com PDX. Conclusão - A inclusão de polidextrose na alimentação pode aumentar a absorção de cálcio e aumentar a concentração dele nos ossos em ratos normais, que podem ser relevantes para diminuir o risco de osteoporose. A gastrectomia parcial não afetou a concentração de cálcio ósseo em 56 dias de período experimental.

DESCRITORES - Prebióticos. Polidextrose. Gastrectomia. Cálcio. Rato.

\section{REFERENCES}

1. Axelson J, Persson P, Gagnemo-Persson R, Hakanson R. Importance of the stomach in maintaining calcium homeostasis in the rat. Gut. 1991; 32:12981302 .

2. Chonan O, Watanuki M. The effect of 6'-Galactooligosaccharides on bone mineralization of rats adapted to different leves of dietary calcium. Int J Vitam Nutr Res. 2003; 66(3):244-49.

3. García Peris P, Velasco Gimeno C. Evolution in the knowledge on fiber. Nutr Hosp. 2007;22 Supp1 2:20-5

4. Hara H, Nagata M, Ohta A, Kasai T. Increases in calcium absorption with ingestion of soluble dietary fiber, guar gum hydrolysate, dependo on the caecum in partial nephrectomized and normal rats. Br J Nutr. 1996; 76:773-784.

5. Hara H, Suzuki T, Aoyama Y. Ingestion of the soluble dietary fibre, polydextrose, increases calcium absorption and bone mineralization in normal and total-gastrectomized rats. Br J Nutr. 2000; 84:655-661.

6. Jie Z, Bang-Yao L, Ming-Jie X, Hai L-Wei, Zu Z-kang, Ting W-Song, Craig SA. Studies on the effects of polydextrose intake on physiologic functions in Chinese people. Am J Clin Nutr. 2000; 72:1503-9.

7. Koga S, Nishimura O, Iwai N, Kishi K, Takeuchi T, Hinohara T, Okamoto T. Clinical evaluation of long-term survical after total gastrectomy. Am J Surg. 1979;138:635-939.

8. Malinowski SS. Nutritional and metabolic complications of bariatric surgery. Am J Med Sci. 2006;331(4):219-25.

9. Nilas L, Christiansen C, Christiansen J. Regulation of Vitamin D and calcium metabolism after gastrectomy. Gut. 1985; 26:252-257.

10. Ohta A, Ohtsuki M, Baba S, Adachi T, Sakata T, Sakaguchi EL. Calcium and magnesium absorption from the colon and rectum are increased in rats fed fructooligosaccharides. J Nutr. 1995; 125: 2417-2424.

11. Ohta A, Ohtsuki M, Hosono A, Adachi T, Hara H, Sakata T. Dietary fructooligosaccharides prevent osteopenia after gastrectomy in rats. J Nut. 1998; 128(1):106-110
12. Prisco C, Levine SN. Metabolic bone disease after gastric bypass surgery for obesity. Am J Med Sci. 2005; 2(329):57-61

13. Reeves PG, Nielson FH, Fahey GCJR. AIN-93 purified diets for laboratory rodents: final report of the American Institute of Nutrition ad hoc writing committee on the reformulation of the AIN-76A rodent diet. J Nut. 1993;123(11):1939-51.

14. Rémésy C, Levrat MA, Gamet I, Demigné C. Cecal fermentations in rats fed oligosaccharides (inulin) are modulated by dietary calcium level. Am J Physiol. 1993; 264:G855-G862.

15. Sakai K, Ohta A, Shiga K, Takasaki M, Tokunaga T, Hara H. The cecum and dietary short-chain fructooligosaccharides are involved in preventing postgastrectomy anemia in rats. J Nut. 2000; 130(6):1608-12.

16. Santos EF, Tsuboi KH, Palu BF, Araujo MR, Andreollo NA, Miyasaka CK. Partial gastrectomy associated to anterior truncal vagotomy: alterations in metabolism of the calcium. Experimental study in rats. ABCD Arq Bras Cir Dig. 2009; 22(2): 105-9.

17. Scholmerich J. Postgastrectomy syndromes - diagnosis and treatment. Res Clin Gastroenterol. 2004;18(5):917-33.

18. Shiga K, Nishimukai M, Tomita F, Hara H. Ingestion of difructose anhydride III, a non-digestible disaccharide, prevents gastrectomy-induced iron malabsorption and anemia in rats. Nutrition. 2006; 22(7-8):786-93.

19. Statsoft, Inc. Statistica for Windows [Computer program manual]. Tulsa, USA, (2000) WEB:http://www.statsoft.com.

20. Zittel TT, Zeeb B, Maier GW, Kaiser GW, Zwirner M, Liebich H, Starlinger M, Becker HD. High prevalence of bone disorders after gastrectomy. Am J Surg. 1997;174:431-38.

Fonte de financiamento: não há Conflito de interesse: não há Recebido para publicação:12/07/2009 Aceito para publicação: 21/09/2009 